\title{
ROLE OF LIS DEPARTMENTS AND ASSOCIATIONS IN PROMOTING READING HABITS
}

\section{DR. SHANTADEVI. T}

Associate Professor and Chairperson,Department of Library and Information Science, Karnataka State Akkamahadevi

\author{
Women's University, Vijayapura, India
}

\begin{abstract}
Library is heart of any education society to promote reading habits among users and helps in developing the reading skills and lifelong literacy skills. LIS Professional Associations are leaders and minds of growth and development of the subject and system. They are playing very important role in professional development of particular subject or system. Identify, define and clarify needs, generate alternative strategies and set objectives, provide appropriate moral and intellectual support required for the continuing professional development is the major goal of the professional associations. In this study an attempt has been made that how the departments of the universities which are offering courses and professional associations in LIS are helping in the promoting reading habits among various categories of users.
\end{abstract}

KEYWORDS: LIS, Professional associations, reading habits, Shodhganga

Received: Nov 28, 2020; Accepted: Dec 18, 2020; Published: Jan 04, 2021; Paper Id.: IJLSRDEC20203

\section{INTRODUCTION}

To improve the quality of education most effectively and efficiently departments which are running courses in concerned subjects and professional associations are playing very important role. Professional development, contemporary applications, leadership, creating awareness and training, extension activities are the tools to achieve the goals of education. Professional socialization of faculty, office bearers heads of the department and education system can encourage the development of a particular subject. The leader's consultative and collaborative role is needed for the purpose. In the development of LIS the departments of the universities and professional associations are major agencies through which goal can be achieve.

Identify, define and clarify needs, generate alternative strategies and set objectives, provide appropriate moral and intellectual support required for the continuing professional development. Participation, policy formulation, extension and practical applications of various dimensions of subjects' development the leader's role is very much required. Association gives the common vision and goals to the profession and gives power and credibility. The association is responsible for keeping the departments/ schools informed of current practices in care provisions, lacks by producing required curriculum framing, reviewing and developing so that the departments/schools implement for the further development.

\section{REVIEWS}

- Shahriza Abdul Karim, N. and Hasan, A. (2007), The study used a survey approach in collecting the data. The population of the study was the undergraduate students from two academic faculties at the university. The study finds that the web site is seen as an increasingly important reading source. Significant differences exist 
between academic programs and types of reading materials and reading resources particularly use the web sites. Some differences in reading habits and attitudes were also observed between male and female participants.

- Samsuddin, S., Mohamed Shaffril, H., Bolong, J. and Mohamed, N. (2019) The purpose of this paper is to investigate the reading habit and attitude among rural communities in the low literacy rate areas in Malaysia. The study found that Moderate levels of reading attitude were obtained from the result of the study, in which several variables produced a significant relationship in the reading attitude (education level, household income and time spent in reading).

- Walia, P. and Sinha, N. (2014). The purpose of this study was to attempt to answer some plausible questions like what do teenagers prefer to read at leisure, how do they read and why do they read? With the rapid changes in information technology, there is tremendous change in means of communication. The findings revealed a decline in sports and outdoor recreational activities during leisure, and only 20.6 per cent teenagers preferred reading during leisure. However, self-perception as an avid reader was expressed by majority (53.8 per cent). Fictions were liked by $>75$ per cent teenagers; however, non-fictions were also liked by majority ( 61.8 per cent). The reading preferences of the children were found to be affected by their age, their gender and the type of schools they attended. A significant inverse relationship of television watching and movie-going was observed with reading time.

- Lindita Skenderi and Suzana Ejupi (2017). This article presents that the Reading is one of the four main language skills and as such it is taught and practiced since an early age. After learning how to read as a main skill, students are also taught by parents and teachers to convert reading to a habit which will help them develop a much needed rich language, better personality, better academic performance, self-confidence in knowledge and many other aspects. The results show whether students enjoy reading, their frequency of reading books, the genres they mostly prefer to read, the reasons that affect their reading habits and similar questions related to reading. The answers show that students mostly read to gain knowledge and for personal satisfaction, while they choose social media and busy schedule at school as the reasons which affect their reading habits.

\section{NEED FOR THE STUDY}

LIS is professional course which deals with theoretical as well as practical aspects of various concepts of library profession. As a course it depends on the library system and library system develops with new inventions and applications in the courses and practices. LIS creates Librarians, information professionals but it needs the existence of library system. The major components of the library system are Library as place, books (in any form) and Users. Users are major component of the library system and satisfying user needs is the major goal of the library system. In the present situation more number of users are not showing interest in the reading. Reading habit is the basic need for development of subject or system or research. Decreasing interest of reading habit is affecting the library system. In this connection the role of departments and associations in developing reading habits and skills is very much needed.

\section{OBJECTIVES}

- To identify the level of reading habits among the various categories of students.

- To identify the role of departments in developing reading skills 
- To identify the role of associations in developing and enhancing reading habits.

\section{METHODOLOGY}

In The present study an analytical method of research has been used. Primary data has been collected through visit and oral discussions among various user groups. The secondary data collected from different sources like curriculum and time tables of identified university LIS departments and conference themes of various LIS associations were analysed. As the secondary data available in websites of the departments and associations has been used for the study.

\section{SUMMARY OF THE DATA ANALYSIS}

\section{Reading Habits among Various Kinds of Users}

- Very less number of users were having reading habits.

- More number of students in primary and high schools were not having reading habits they read only textbooks and refer notes.

- Majority of students in higher education like under graduate, professional courses like B.Ed., M.Ed., MCA, MBA and other post graduate student except literature and very few habitual readers were not having reading skills and they are mostly depend on capsule information.

\section{University LIS Departments in Karnataka}

- In this study 09 university LIS departments syllabus has been analysed among 09 no one department having the syllabus/ curriculum on promoting reading habits.

- Some of courses like information literacy skills, user studies and different types of library systems having as a part of syllabus like user studies, user education, user orientation, information seeking patterns etc.,.

- Analysed syllabus of different universities in Karnataka which are offering LIS courses are having very less amount of syllabus has been included about promoting reading habits.

- Information literacy and information literacy skills courses will support little about reading skills but these also not recommend how to improve reading skills among users. No theory and practical course on promoting reading habits/skills among user for forthcoming library professionals.

- In the time table leisure hours has been mentioned as library hours/ library work for the students who are learning the course.

\section{Research on Reading Habits}

- For this study all the LIS theses submitted to different universities in Karnataka and available in SHODHGANGA has been analysed.

- Among 190 theses only 20 theses are about reading habits, reading skills, user studies and information literacy skills and effect of other variables on reading habits.

- Very less i.e. only $10 \%$ of the research on assessing the reading habits of the users.

- In these research studies only few suggestions / recommendations has been given for promotion of reading habits. 


\section{LIS Professional Association's Conferences}

- In this important LIS professional associations conference themes and sub themes has been analysed.

- The conference themes and sub themes of CGLA: central Government Library Association, IASLIC: Indian Association of Special Libraries and Information Centres, IATLIS: Indian Association of Teachers of Library and Information Science, ILA: Indian Library Association, SALIS: Society for Advancement of Library and Information Science, SIS: Society for Information Science, KSLA: Karnataka State Library Association, IALA: Indian Academic Library Association etc. has been analysed.

- Analysis shows that CGL A's five conferences on vision- 2020,profession and education, IATLIS $22^{\text {nd }}$ conference on Quality of education in LIS, $23^{\text {rd }}$ conference on Building curriculum with a difference vision for LIS education in the $21^{\text {st }}$ century, $25^{\text {th }}$ conference on Changing face of LIS education, and $28^{\text {th }}$ conference on Emerging challenges in LIS education, ILA's 64 international conferences only few conference on LIS education, curriculum library services in some information is available on reading habits.

- More number of conference themes are on latest concepts like application of ICT to library, Networking, Digital library system, open access system, quality management, Information Literacy skills etc.

\section{FINDINGS OF THE STUDY}

- Majority of the students from primary education to post graduate education were not the habitual/ regular readers.

- $\quad$ More number of students were not having reading skills

- Very less number of curriculums framed on promoting reading habits among users in the LIS departments courses.

- Very less amount of practical approach has been applied on promoting reading habits

- Very less i.e. only $10 \%$ of the research on assessing the reading habits of the users.

- More number of conference themes of LIS professional associations are on latest concepts like application of ICT to library, Networking, Digital library system, open access system, quality management, Information Literacy skills etc.,.

- $\quad$ Finds very less scope to promoting reading habits among users.

\section{SUGGESTIONS}

- To promote the reading habits all types of libraries should take remarkable initiatives.

- The libraries and information sources should be made available to all users.

- Public libraries should be made attractive to the users.

- More research to be conducted on promoting reading habits according to the needs of the users

- Professional association as major leaders in developing a subject and system to be organize more conferences and seminars on promoting reading habits.

- Considering primary to higher level education system more number of orientation, training programmes and workshops to be conducted on promoting reading habits.

\section{CONCLUSIONS}

Reading is major tool to inculcate and develop knowledge among the users. Libraries are the facilitators of the resources 
and skills to develop reading habits. From the primary education itself if it provided by the good library facilities, relevant resources and full time librarian the users can develop reading skills. The departments and the professional associations make dominant role in developing a subject by providing various facilities like curriculum development, conducting training and workshops to professionals on promoting reading habits.

\section{REFERENCES}

1. Walia, P. and Sinha, N. (2014), "Changing trend in reading habits of teenagers in Delhi: An impact assessment of demographic and environmental variables", Library Review, Vol. 63 No. 1/2, pp. 125-137. https://doi.org/10.1108/LR-032013-0038

2. Venkateswaran, N. "LOGISTICS INFORMATION SYSTEM (LIS) AT PHARMA FIRM-AN EVALUATION." International Journal of Business and General Management (IJBGM) ISSN(P): 2319-2267; ISSN(E): 2319-2275 Vol. 7, Issue 3, Apr - May 2018; $11-18$

3. Shahriza Abdul Karim, N. and Hasan, A. (2007), "Reading habits and attitude in the digital age: Analysis of gender and academic program differences in Malaysia", The Electronic Library, Vol. $25 \quad$ No. 3 , pp. 285 298. https://doi.org/10.1108/02640470710754805

4. BENIWAL, PRIYANKA, and CHANDRA KALA SINGH. "ROLE OF SOCIO-ECONOMIC STATUS IN ENHANCING ADOLESCENTS'CREATIVE THINKING." International Journal of Humanities and Social Sciences (IJHSS) 6.1, Dec - Jan $2017 ; 37-42$

5. Samsuddin, S., Mohamed Shaffril, H., Bolong, J. and Mohamed, N. (2019), "Understanding the reading habit and attitudes among the rural community in low literacy rate areas in Malaysia: Rural library perspectives", Library Management, Vol. 41 No. 1, pp. 39-52. https://doi.org/10.1108/LM-06-2019-0037

Viswanathan, V., and I. Sasireka. "Use of Library Electronic Resources Among Selected Arts And Science Colleges In Tamil Nadu." International Journal of Library Science and Research (IJLSR) 6.4 (2016): 17-22.

6. Sehn, T. and Fragoso, S. (2015), "The synergy between eBooks and printed books in Brazil", Online Information Review, Vol. 39 No. 3, pp. 401-415. https://doi.org/10.1108/OIR-01-2015-0006

7. Naik, Umesha. "Library Automation Software: A Comparative Study of Koha, Libsys, Newgenlib and Soul." International Journal of Library Science and Research (IJLSR) 6.6 (2016): 77-86.

8. Lindita Skenderi and Suzana Ejupi (2017). The reading habits of university students in Macedonia. Conference Paper. December 2017. https://www.researchgate.net/publication/328492200

9. Firima Zona Tanjung, Ridwan, and Uli Agustina Gultom. Reading habits in digital era: A research on the students in Borneo University. Vol. 20, No. 2, October 2017. doi.org/10.24071/llt.2017.200209.

10. Samuel Kwame Ameyaw and Sylvester Kwabena Anto. Read or Perish: Reading Habits among Students and its Effect on Academic Performance: A Case Study of Eastbank Senior High School - Accra. Library Philosophy and Practice (e-journal). 2018 .

11. Ms. Kushmeeta Chettri, Dr S.K. Rout. IOSR Journal of Humanities and Social Science (IOSR-JHSS) Volume 14, Issue 6 (Sep. Oct. 2013), PP. 13-17 e-ISSN: 2279-0837, p-ISSN: 2279-0845. www.Iosrjournals.Org.

12. Khreisat, M. and Kaur, S. (2014), "English recreational reading habits of Arab Jordanian EFL tertiary students", Education, Business and Society: Contemporary Middle Eastern Issues, Vol. 7 No. 1, pp. 17-32. https://doi.org/10.1108/EBS-08-20130030 . 
13. Rabaud, C., Mamode Khan, N. and Rampat, S. (2018), "Independent and digital reading among undergraduates: the case of the University of Mauritius", Journal of Applied Research in Higher Education, Vol. 10 No. 3, pp. 296310. https://doi.org/10.1108/JARHE-09-2017-0117

14. https://www.ilaindia.net/

15. http://www.iaslic1955.org.in/Default.aspx?PageID $=62$

16. http://cgla.org.in/

17. http://kalaonline.com/

18. http://www.alaindia.org/

19. https://shodhganga.inflibnet.ac.in/ 